\title{
The summer aerosol in the central Arctic 1991-2008: did it change or not?
}

\author{
J. Heintzenberg ${ }^{1}$ and C. Leck ${ }^{2}$ \\ ${ }^{1}$ Leibniz Institute for Tropospheric Research, Permoserstr. 15, 04318 Leipzig, Germany \\ ${ }^{2}$ Department of Meteorology, Stockholm University, 10691 Stockholm, Sweden
}

Correspondence to: J. Heintzenberg (jost@tropos.de)

Received: 22 December 2011 - Published in Atmos. Chem. Phys. Discuss.: 11 January 2012

Revised: 16 April 2012 - Accepted: 17 April 2012 - Published: 4 May 2012

\begin{abstract}
In the course of global warming dramatic changes are taking place in the Arctic and boreal environments. However, physical aerosol data in from the central summer Arctic taken over the course of $18 \mathrm{yr}$ from 1991 to 2008 do not show systematic year-to-year changes, albeit substantial interannual variations. Besides the limited extent of the data several causes may be responsible for these findings. The processes controlling concentrations and particle size distribution of the aerosol over the central Arctic perennial pack ice area, north of $80^{\circ}$, may not have changed substantially during this time. Environmental changes are still mainly effective in the marginal ice zone, the ice-free waters and continental rims and have not propagated significantly into the central Arctic yet where they could affect the local aerosol and its sources. The analysis of meteorological conditions of the four expedition summers reveal substantial variations which we see as main causes of the measured variations in aerosol parameters. With combined lognormal fits of the hourly number size distributions of the four expeditions representative mode parameters for the summer aerosol in the central Arctic have been calculated. The combined aerosol statistics discussed in the present paper provide comprehensive physical data on the summer aerosol in the central Arctic. These data are the only surface aerosol information from this region.
\end{abstract}

\section{Introduction}

The Arctic has changed substantially over the past decades and will continue to do so dramatically in the course of global warming in the 21 st century (e.g., Kattsov et al., 2010). There are many facets to this change. First and foremost this change concerns the Arctic sea ice. Ice extent has been shown to decrease for more than a quarter of a century and there is evidence that the rate of decline has accelerated during the last decade (Maslanik et al., 2011). This trend cannot be explained by internal variability and natural causes alone (Kay et al., 2011) and will continue with further global warming. Not only the extent but also ice thickness has been demonstrated by different approaches to have decreased for many decades (Kwok et al., 2009; Kwok and Rothrock, 2009). Changes in ice advection speed and deformation rate have also been reported. Increasing deformation means stronger fracturing, hence more lead opening, which plays a fundamental role in the albedo feedback loop and sea ice decline (Rampal et al., 2009). Sea ice losses now extend into the central Arctic and are not distributed homogeneously around the pole.

A number of possible explanations for the rapid changes in Arctic sea ice are being discussed. The atmospheric aerosol may contribute to changes in Arctic sea ice via several pathways. All potential aerosol-related Arctic changes concern the energy budget of the surface and lowermost atmosphere. The atmospheric import of anthropogenic light absorbing "black carbon" particles (BC) from lower latitudes has been hypothesized to contribute to the Arctic warming by reducing surface albedo (Hansen and Nazarenko, 2003; Koch et al., 2011) and have thus been suspected to be one of several amplifying factors in Arctic warming (Serreze and Barry, 2011). However, a recent large survey of impurities in Arctic snow by Doherty et al. (2010) concluded that the BC content of Arctic snow appears to be no higher now than in 1984, so it is doubtful that $\mathrm{BC}$ has contributed to the rapid decline of Arctic sea ice in recent years. 
For want of data up until the early Nineteen Nineties the pack ice covered central Arctic boundary layer had been assumed to be practically free of aerosol sources. Early studies of the Arctic summer aerosol that did not extend much beyond the marginal ice zone had found very low particle number and mass concentrations within the atmospheric boundary layer (Lannefors et al., 1983), which would preclude a substantial direct aerosol forcing of the radiation budget. The results of the first three Oden expeditions in 1991, 1996, and 2001, however, clearly demonstrated the existence of a marine primary biological particle source within the pack ice region (Leck et al., 1996, 2002; Leck and Bigg, 1999; Bigg and Leck, 2001b) and indicated potential links of this source with boundary layer fog and cloud processes (Leck and Bigg, 1999; Bigg and Leck, 2001a; Leck et al., 2004; Lohmann and Leck, 2005; Heintzenberg et al., 2006), which have been confirmed recently (Orellana et al., 2011). Changing sea ice conditions have severe effects on marine biology in the Arctic (Zhang et al., 2010), which will not only affect the source strength of the primary marine biogenic organic particles but also affect atmospheric gas phase composition in terms of biogenic dimethyl sulfide, DMS, and its oxidation products (Leck and Persson, 1996b). The ongoing and future Arctic warming possibly will cause an increase in biological productivity that will not only affect DMS production but also that of bacteria and viruses, which are suspected to be major players in the generation of marine primary biogenic particles (Orellana et al., 2011). Climate changes are not restricted to marine biology within the Artic pack ice region but extend to the coastal Arctic Ocean where the biological productivity has recently increased (Tremblay et al., 2011), which in turn would influence the cloud forming processes over the Arctic shelf areas.

Besides surface albedo the low Arctic summertime clouds are the most important factor regulating the surface radiation budget (Intrieri et al., 2002; Sedlar et al., 2010). Complex physical and chemical processes connect clouds and the atmospheric aerosol. Thus, depending on their number, size and hygroscopic properties even the low concentrations of the summer Arctic aerosol may affect low clouds significantly. That these clouds constitute a warming factor for the surface most of the year, rather than a cooling (Intrieri et al., 2002; Tjernström, 2005) further increases the complexity of the aerosol-cloud-radiation-albedo relationship in the Artic region. Any ice cover raises the albedo of the surface whereas a scarcity of aerosol particles available to act as cloud condensation nuclei leads to relatively low cloud albedo compared to similar clouds at lower latitudes. Together this complexity of the connection between sea ice, aerosol, clouds and radiation budget makes small changes in any of the components very important for the heat transfer to the ice and the subsequent summertime ice-melt.

Changes in Arctic clouds have been documented by Eastman and Warren (2010) and have been related to sea ice loss by Vavrus et al. (2011). Through ice and cloud feedbacks the ongoing changes in sea ice will lead to strong further Arctic warming (Liu et al., 2009).

Kattsov et al. (2010) summarize the ongoing and expected changes in the Arctic and the related state of research and conclude "Meaningful prediction/projection of the Arctic sea-ice conditions for the coming decades and beyond requires determining priorities for observations and model development, evaluation of the ability of climate models, to reproduce the observed sea ice behavior as a part of the broader climate system, improved attribution of the causes of Arctic sea-ice change, and improved understanding of the predictability of sea-ice conditions on seasonal through centennial timescales in the wider context of the polar climate predictability".

Their ice related conclusion holds just as well for the atmospheric part of the Arctic climate system: Within the Arctic pack ice region there are very few studies of atmospheric composition and its connection to climate-related processes. At the surface we essentially have only the results of the four Oden expeditions in 1991 (Leck et al., 1996), 1996 (Leck et al., 2001), 2001 (Leck et al., 2004; Tjernström et al., 2004), and 2008 (Paatero et al., 2009) that focused on the atmospheric aerosol and its connection with sea ice, marine biology, clouds, and climate. In the light of the recent and ongoing Arctic changes introduced above the present study investigates potential changes in the aerosol number population over the central ice-covered Arctic in summer. We will use the aerosol data collected during the four Oden expeditions, covering nearly two decades, during which ice extent and thickness diminished substantially.

After an introduction of the experimental methods details of the data sets of the four expeditions will be given. Before a structural analysis based on lognormal functions fitted to hourly average number size distributions the main characteristics of the high Arctic aerosol and the ice and meteorological conditions of the central Arctic are presented. These discussions are followed by the statistics of physical aerosol parameters of the four expedition years and their connection with air mass transport over the pack ice.

\section{Experimental}

The analyses presented here rely on measurements carried out from the icebreaker Oden during the months July, August and early September 1991 (IAOE-91), 1996 (AOE-96), 2001 (AOE-01), and 2008 (ASCOS-08). Figure 1 shows the routes of the four expeditions together with the average ice edge in mid-August of 2008. Details of the expeditions in the years 1991, 1996, and 2001 can be found in Leck et al (1996; 2001; Leck et al., 2004), and Heintzenberg et al. (2006), respectively. For 2008 cruise details see Paatero et al. (2009). For all years we evaluate only data for periods when the ship was within the central pack ice area (cf. Table 1). 
Table 1. Start and end dates of the aerosol data taken within the central pack ice in 1991, 1996, 2001, and 2008, number of hourly averages in ice, lower and upper diameters of the scanned size ranges in nanometers and the number of logarithmically evenly spaced diameters.

\begin{tabular}{lllcccc}
\hline Year & Start date & End date & Hours & $\begin{array}{c}\text { Lower diameter } \\
\text { limit }\end{array}$ & $\begin{array}{c}\text { Upper diameter } \\
\text { limit }\end{array}$ & $\begin{array}{c}\text { Number of } \\
\text { diameters }\end{array}$ \\
\hline 1991 & $1991-08-18$ 18:00 UTC & 1991-09-26 22:00 UTC & 721 & 3 & 571 & 33 \\
1996 & $1996-07-26$ 11:00 UTC & 1996-09-04 23:00 UTC & 499 & 5.1 & 613 & 27 \\
2001 & $2001-07-10$ 00:00 UTC & 2001-08-25 23:00 UTC & 673 & 3 & 900 & 41 \\
2008 & $2008-08-04$ 06:00 UTC & 2008-09-05 17:00 UTC & 418 & 3 & 800 & 45 \\
\hline
\end{tabular}

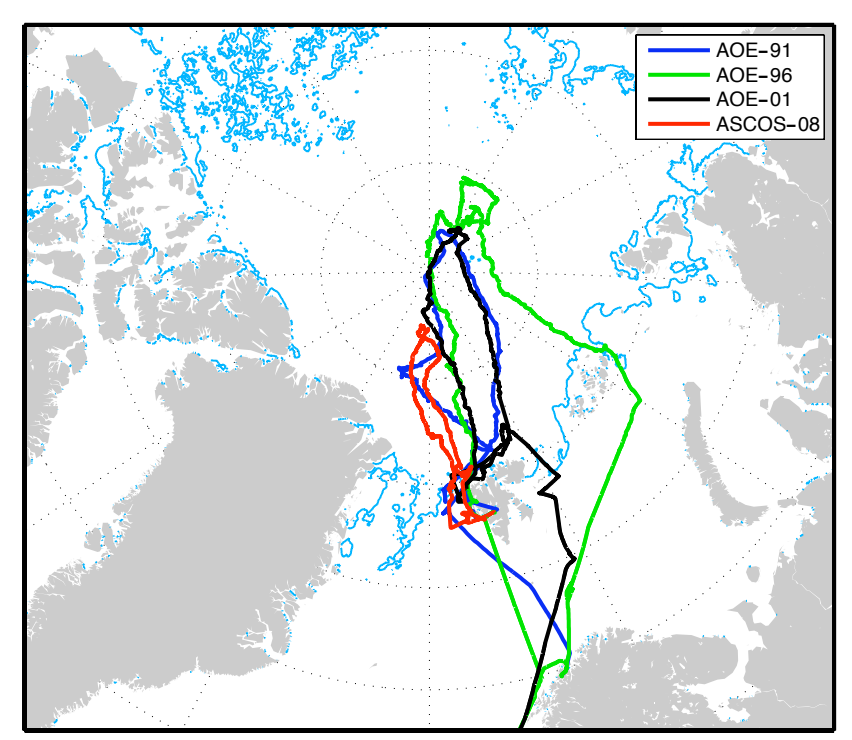

Fig. 1. Routes of the Oden Expeditions in 1991, 1996, 2001, and 2008. The blue line delineates the ice edge on 12 August 2008.

In all Oden expeditions the aerosol was sampled through the same $\mathrm{PM}_{10}$-inlet mast. The inlet was an integrated part of an air sampling manifold (facing the bow of the ship), which was erected on top of a laboratory container located on the 4th deck of Oden to maximize both the distance from the surface and from the ship's superstructure. The inlet manifold extended at an angle of $45^{\circ}$ to about three meters above the container roof so that the height of the inlet above sea level was about $25 \mathrm{~m}$. At the PM10-inlet an Andersen impactor (Andersen Inc. Atlanta, GA) excluded particles larger than $10 \mu \mathrm{m}$ aerodynamic diameter at ambient relative humidity (RH) from the sample stream, which was conducted through a $9 \mathrm{~cm}$ inner diameter pipe into the aerosol laboratory. Because of the high flow rate through this inlet, (ca. 11001 per minute), the residence time between inlet point and the first air take off from this inlet was about $0.2 \mathrm{~s}$. Further details on the location and the design of the aerosol inlet can be found in Leck et al. (2001).

The Tandem Differential Mobility Particle sizers (TDMPS) deployed to measure the number size distributions of dry sub-micrometer particles used pairs of very similar differential mobility analyzers (DMAs) in all years. The TSI 3010 counters used in the DMAs were size and concentration calibrated against an electrometer and the TSI 3025 counters for particle sizes below $20 \mathrm{~nm}$ diameter in the standard way (Stolzenburg, 1988). In 1996 a second, modified TSI 3010 was utilized to extend the data from 20 to $5 \mathrm{~nm}$ instead of a TSI 3025 . The size ranges and numbers of diameters that were scanned in the four set ups are collected in Table 1. Individual scans took about ten minutes.

\section{Data sets and data processing}

\subsection{Particle number size distributions}

Table 1 gives the extent of the data sets evaluated in the present study. In order to interpret the aerosol data the following processing steps were applied. The raw data were inverted with algorithms consisting of modifications of a standard TDMPS-inversion (e.g., Stratmann et al., 1997). The DMA data were inverted considering the width of the transfer function and the multiple charge distribution. The transfer function widths for the DMAs were taken from calibrations of the Vienna-type DMAs in Birmili et al. (1997). Each channel was first corrected for transmission efficiency by the transfer function area. Then the counts were corrected by applying a matrix of charge corrections from Wiedensohler (1988). Then the data were normalized to standard temperature and pressure, and corrected for size-dependent inlet transmission efficiency and size-dependent CPC counter efficiency. Finally the channels were transferred to $d N / d \log D_{p}$ by multiplying the matrix by $d \ln Z \mathrm{p} / d \log D_{p}$.

The individual DMA scans were checked manually for continuity, any individual record that had a total number concentration that was higher by more than a factor of five compared to both its neighbors was flagged as polluted. Direct contamination from the ship was excluded by using a pollution controller in direct connection to the sampling manifold. It consisted of a TSI-3025 UCPC connected to the control system described by Ogren and Heintzenberg (1990). Wind sectors safe from pollution had been established by releasing massive amounts of smoke from various parts of the ship, while varying wind speed and direction by maneuvering the ship (Leck et al., 1996). Provided that the wind was within 
$\pm 70^{\circ}$ of the bow and stronger than $2 \mathrm{~m} \mathrm{~s}^{-1}$, no ship pollution reached the sample inlets. In 2001 and 2008 a third criteria was added excluding data when one-minute toluene concentrations measured with the Proton Transfer Reaction Mass Spectrometry system of the University of Innsbruck increased by $75 \%$ over their ten-minute running mean. To maximize sampling time safe from pollution our strategy in addition was to keep the sampling manifold facing upwind, by periodically changing the ship's orientation, to avoid sampling of ship exhausts.

For the TDMPS data collected in 1991 only hourly averages had been archived. Thus, for the present comparison the data of all years were converted to hourly averages. From these averages of the inverted size distributions total number $(N)$, surface $(\mathrm{S})$, and volume $(V)$ concentrations were calculated. For a comparative structural analysis of the particle size distributions the average distributions were fitted with lognormal functions allowing two to six modes. Geometric mean diameters $\left(D_{\mathrm{g}}\right)$ and geometric standard deviations $\left(\mathrm{SIG}_{\mathrm{g}}\right)$ were found by random search over given numerical ranges while total number concentrations of the modes were determined by least square fits to the measured data. In each fit the solution was utilized that with a minimum number of modes satisfied the condition of an average relative deviation between measured and fitted size distribution of less than $25 \%$.

With the fitted size distributions the internal structure of the particle size distributions was investigated in two ways. In each fit the number concentration below $26 \mathrm{~nm}$ was determined (N26). Secondly, in each fitted distribution the diameter of the deepest minimum in number concentration between 30 and $150 \mathrm{~nm}$ was determined as an indication of the diameter down to which cloud processing may have modified the measured aerosol following Hoppel et al. (1986), referred to as the Hoppel diameter (DHO). Depending on the year between $72 \%$ and $83 \%$ of all size distributions exhibited an identifiable DHO (cf. Table 3). For these size distributions Aitken particle number concentrations (NAIT) were calculated between $26 \mathrm{~nm}$ and DHO. Accumulation mode number concentrations (NACC) were calculated between DHO and $600 \mathrm{~nm}$. The latter upper limit was chosen as a compromise between different upper DMA limits in different years (cf. Table 1) and an effort to minimize potential effects of coarse particle sea spray and fog drop residues on the results.

\subsection{Air mass travel time over the pack ice since last contact with the open sea}

Three-dimensional ten and five day back-trajectories of the air reaching Oden's position were calculated for an arrival height of $100 \mathrm{~m}$ above surface level at hourly intervals. During the three earliest expeditions (1991, 1996, and 2001) the trajectories were calculated with the R. McGrath (1989) model at the European Center of Medium-range Weather Forecasts (ECMWF) using their analyzed wind and pres-

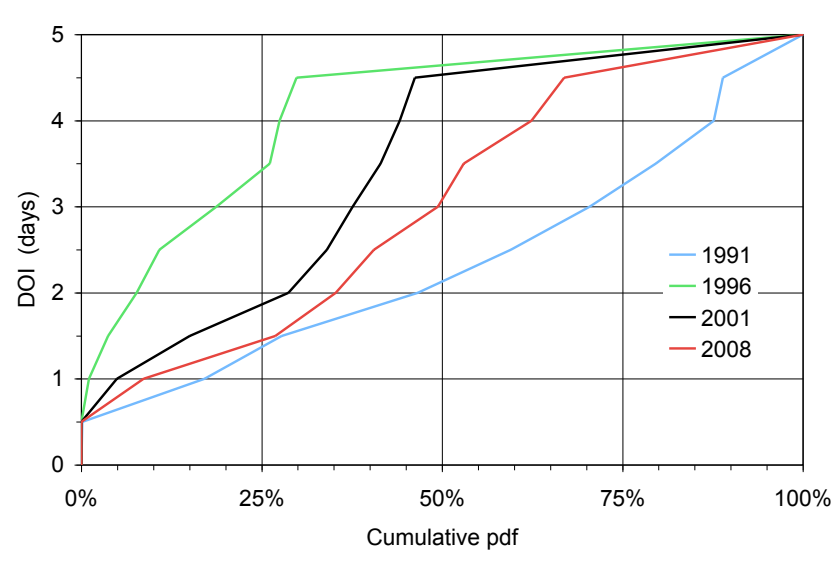

Fig. 2. Cumulative probability distributions of travel times over ice (DOI, days) for the Oden expeditions in 1991, 1996, 2001, 2008. All travel times beyond five days are given the value five.

sure fields. The 2008 expedition used the HYSPLIT (HYbrid Single-Particle Lagrangian Integrated Trajectory) Model developed at NOAA Air Resources Laboratory (Draxler and Rolph, 2003). For the extent and distribution of the pack ice, ice maps prepared by NESDIS/Synoptic analyses branch based on NOAA-11 and GOES-7 images and ice maps prepared by the Norwegian meteorological institute have been used in 1991 and 1996. The years 2001 and 2008 were evaluated with ice maps from Satellite-sensor, AMSR-E, "level 1A" with the data sourced from NSIDC (Boulder), United States, finalized at Bremen University, http://iup.physik.uni-bremen.de:8084/amsr/amsre.html.

With the help of the back trajectories and ice maps the time elapsed since the air was last in contact with the open ocean was computed in the same way as Nilsson (1996). Basic statistics of DOI for the four years are listed in Table 4 while cumulative probability distribution functions of DOI for the four years are displayed in Fig. 2. From the total data sets of the four expeditions only data with DOI $>0.5$ days have been selected for the present study as representative for the pack ice covered inner Arctic.

\section{Main characteristics of the high Arctic aerosol and related processes}

During the four expeditions it has been possible to detect particles down to diameters of about $3 \mathrm{~nm}$. New particle formation events were recorded at different latitudes north of $78^{\circ} \mathrm{N}$ in open water, in the marginal ice zone with partly icecovered water as well as in the pack ice area. In the summer Arctic concentrations of particles $<10 \mathrm{~nm}$ are usually very low, but on frequent occasions, relative to lower latitudes, concentrations may suddenly increase dramatically for 5-12 hours with hardly any detected subsequent growth, before particles are scavenged by fog or precipitation (Karl et al., 2012). During the nucleation events high concentrations 
Table 2. $5 \%, 50 \%$, and $95 \%$ percentiles of hourly averages of total number $\left(N, \mathrm{~cm}^{-3}\right)$, total surface $\left(\mathrm{S}, \mu \mathrm{m}^{2} \mathrm{~cm}^{-3}\right)$, and total volume $(V$, $\mu \mathrm{m}^{3} \mathrm{~cm}^{3}$ ) concentrations for time periods listed in Table 1 of the Oden expeditions in 1991, 1996, 2001, and 2008.

\begin{tabular}{llllllllll}
\hline Year & $N$ & $N$ & $N$ & $\mathrm{~S}$ & $\mathrm{~S}$ & $\mathrm{~S}$ & $V$ & $V$ & $V$ \\
\hline Quantile & $5 \%$ & $50 \%$ & $95 \%$ & $5 \%$ & $50 \%$ & $95 \%$ & $5 \%$ & $50 \%$ & $95 \%$ \\
1991 & 9 & 83 & 570 & 0.16 & 3.0 & 11 & 0.006 & 0.11 & 0.42 \\
1996 & 18 & 146 & 720 & 0.47 & 3.0 & 13 & 0.013 & 0.12 & 0.67 \\
2001 & 9 & 94 & 710 & 0.30 & 2.1 & 11 & 0.007 & 0.08 & 0.43 \\
2008 & 12 & 135 & 510 & 0.28 & 4.4 & 9.3 & 0.009 & 0.13 & 0.39 \\
\hline
\end{tabular}

of small particles are generated, ranging from several hundreds to $\approx 1000 \mathrm{~cm}^{-3}$ - in an atmosphere that is characterized by very low total aerosol number concentrations, typically around $100 \mathrm{~cm}^{-3}$ and occasionally even less than $10 \mathrm{~cm}^{-3}$ (cf. Lannefors et al., 1983; Bigg et al., 1996; Covert et al., 1996, and Table 2). A common feature of all events with enhanced levels of 3-5 nm particles is that the simultaneous increases in particle number also occurred in other distinct size ranges $<50 \mathrm{~nm}$ diameter showing relatively high concentrations (up to $500 \mathrm{~cm}^{-3}$ ) for a few hours (Leck and Bigg, 1999; Leck and Bigg, 2010; Karl et al., 2012).

At sizes $>10 \mathrm{~nm}$ number concentrations increase with size up to a maximum that lies between 20 and $60 \mathrm{~nm}$ (Kerminen and Leck, 2001; Leck and Bigg, 2005b; and Section 6 of this study) a smaller range compared with other marine locations where the maximum lies in the range 20 to $100 \mathrm{~nm}$ diameter (Heintzenberg et al., 2004). The number maximum in this size range is referred to as the "Aitken mode" after the pioneer of aerosol research in the late 19th century (Spurny, 2000). A concentration minimum usually referred to as the "Hoppel" minimum/gap (Hoppel et al., 1986) follows which has been identified at particle diameters between 50 and about $200 \mathrm{~nm}$ (Heintzenberg et al., 2004). Another maximum follows, coined by Whitby (1978) "the accumulation mode", lying at about $100 \mathrm{~nm}$ in polar air and up to $200 \mathrm{~nm}$ or more at low latitudes over the oceans (Heintzenberg et al., 2004). Further maxima at sizes larger than $1000 \mathrm{~nm}$ (the "coarse mode", (Whitby, 1978)), are often inconspicuous in number distributions but contribute substantially to aerosol volume and mass concentrations. A more efficient growth process of Aitken mode particles into the accumulation mode than growth by condensation of vapors can occur through liquid phase oxidation processes of dissolved gases in clouds. In the inner Arctic sulfur precursor concentrations $\left(\mathrm{SO}_{2} 5-20 \mathrm{pptv}\right.$; (Leck and Persson, 1996a; Kerminen and Leck, 2001)) appear to be too low to allow for substantial liquid phase oxidation. However, these processes may occur in air masses with higher DMS concentrations on their way from the open ocean via the marginal ice zone, in which a substantial DMS source is located (Leck and Persson, 1996a; Leck and Persson, 1996b).

In addition to creation of accumulation mode particles through growth processes, (secondary particles), primary particles can be directly injected into this mode. An example is the production of sea salt particles from bursting bubbles generated by strong wind in surface water (e.g., Lewis and Schwartz, 2004). Over the summer pack ice wind speeds are typically low $\left(<5 \mathrm{~m} \mathrm{~s}^{-1}\right)$, and the extent of open water in leads in the pack ice is usually modest (10-30\%) so that fetches are short and the generation of waves is limited. In spite of the low winds a recent study confirmed both the presence and temporal variability of a population of bubbles (diameters $<500 \mu \mathrm{m}$ ) within the open leads, and a nonwave bubble source mechanism driven by the surface heat flux was proposed (Norris et al., 2011). However transmission electron microscope studies of individual particles by Bigg and Leck (2001a, 2008); Leck et al. (2002); Leck and Bigg $(2005 a, b)$ over the pack ice have failed to find evidence of sea salt particles $<200 \mathrm{~nm}$. To explain this lack of accumulation mode sea salt particles less than $200 \mathrm{~nm}$ the same authors proposed a bubble-induced mechanism responsible for transporting polymer microcolloids and their gelrich material (called exopolymer secretions (EPS) or microgels) from the bulk seawater into the open lead surface microlayer $(<1000 \mu \mathrm{m}$ thick at the air-sea interface). The EPS material contains highly surface-active polysaccharides, peptides and proteins (Orellana et al., 2011; Gao et al., 2012). It was suggested that these highly surface-active polymer gels could attach readily to the surface of rising bubble and self-collide to form larger aggregates. Consequently, polymer gels and their aggregate production, as well as embedded solid particles such as bacteria, phytoplankton and its detritus can be carried to the surface microlayer by rising bubbles. Before bursting, bubbles rest in the microlayer and therefore are likely to have walls composed largely of exopolymers that give them strength, with embedded particulate matter that may be points of weakness as the water drains from between the walls. Following the burst, the film drop (Blanchard and Woodcock, 1957) fragments would be drops of surfactant material with salt-free water and any particles attached to the fragments. Fresh aggregates with microcolloids with polymer gel on them could act as Cloud Condensation Nuclei (CCN) directly because of the gel's strong surface-active properties. Those that have lost their gel could still act as sites for condensation of the oxidation products of DMS. Evidence that this happens is the detection of insoluble 
marine microcolloids in most (50-90\% of total number) of the predominantly sulfate particles (Leck and Bigg, 2005b). Their acquisition of sulfuric acid provides a much more direct and faster path to CCN status than having to grow from particles that nucleated from the gas phase. Moreover, a model study by Lohmann and Leck (2005) found it necessary to invoke a highly surface-active Aitken mode, assumed to be polymer gels, externally mixed with a sulfur-containing population in order to explain the observed $\mathrm{CCN}$ over the pack ice. For the first time a highly specific antibody developed against seawater biopolymers was applied to cloud, fog, and particle samples (Orellana et al., 2011) collected during ASCOS. The result confirmed that both the airborne and cloud microgels originated in the pack ice surface microlayer. This lends extra weight to the importance of the surface microlayer for cloud processes of the high Arctic.

Even the ability of jet drop particles that are mainly composed of sea salt to act as cloud condensation nuclei is not straightforward. Their observed coating of highly surfaceactive exopolymers over the Arctic pack ice area (Leck et al., 2002) is known to revert to short chain compounds after exposure to ultraviolet light (Orellana et al., 2011). This might make them less water soluble than if they only consisted of sodium chloride.

\section{Variability in ice and meteorological conditions in the summers of 1991, 1996, 2001 and 2008}

\subsection{Ice conditions}

The introduction summarized the recent changes in the Arctic that might have affected the aerosol data taken during the Oden expeditions. Both, ice extent provided by the U.S. National Snow and Ice Data Center (http://nsidc.org/data/ seaice_index/index.html) and ice thickness data in Kwok and Rothrock (2009) show a general downward trend during the years of the Oden expeditions, albeit not monotonous. Whereas the extent showed no clear reduction during the first two expeditions there was a strong decrease in the first decade of the 21 st century.

The melting of sea ice entails processes that enhance biological activity in the open leads. Nutrients are released from the winter storage in ice and remain in a stable water layer below. The release and accumulation of these nutrients coupled with increasing light levels in the surface waters favor phytoplankton growth and biological activity in general. Moreover, the ice itself is a source of starting material of phytoplankton, which is released into the mixed layer during melting (Smith and Nelson, 1985). Enhanced plankton growth in turn will affect the surface microlayer and related aerosol emissions.

\subsection{Meteorological conditions during IAOE-91}

From August to mid-September weather conditions were typical for the central Arctic Ocean summer. Advection of air masses from the Atlantic sector and open seas north of Siberia dominated over shorter periods of air being either advected from continents or subsiding from the free troposphere. In general this gave weather conditions with high relative humidity (90-100\%) and air temperatures in the vicinity of $0^{\circ} \mathrm{C}$, as the relatively warmer maritime air was cooled when advected over the pack ice. An optically thin, low cloud cover of stratus was present most of the time. There were frequent fog episodes (cf. Table 4). Only five well-defined fronts passed the ship. This slowly changing mesoscale or synoptic scale meteorology appeared to be typical of the region at these times of the year. Winds were in general low, centered around $3 \mathrm{~m} \mathrm{~s}^{-1}$ ( 25 and 75 percentiles $5-7 \mathrm{~m} \mathrm{~s}^{-1}$ ). Despite their meteorological similarities during most of the time, the back trajectories often showed considerable variations. The trajectories spent relatively short times (median about two days, cf. Table 4 and Fig. 2) over the pack ice before reaching Oden.

\subsection{Meteorological conditions during AOE-96}

Nilsson and Barr (2001) have described the synoptic meteorology during AOE-96 (mid-July to end of August), which at the surface was influenced by frontal zones and persistent high pressure ridges. Much of the time the ship's position was in the saddle of the pressure pattern topography created by a high pressure ridge along an axis from Scandinavia to eastern Siberia, intersected by a trough of low pressure along a line from Greenland to central Siberia. Nilsson and Barr pointed out that there were large differences from the meteorology of IAOE-91 with its more frequent cyclonic circulations. This resulted in both a weaker synoptic variability and less advection from south of the ice edge than during IAOE-91. The sampled air spent a median time of more than five days over the pack ice compared to two days during IAOE-91. Anticyclonic circulations prevailed during several weeklong periods and resulted in air masses with clear skies and mainly low wind speeds $\left(<5 \mathrm{~m} \mathrm{~s}^{-1}\right)$ and rapid melting of the fringes of the open leads. Relative to 1991 considerably fewer fog periods were encountered (cf. Table 4). A comparison of clouds and fogs during the two expeditions reflects this difference. Surface temperatures were in the range of -3 to $5^{\circ} \mathrm{C}$.

\subsection{Meteorological conditions during AOE-01}

The expedition lasted from the beginning of July to the end of August and was characterized by high synoptic-scale activity. The pressure anomaly showed stronger sub-tropical highpressure cells and lower air pressure over large parts of the Arctic, in a pattern from the North Atlantic along the Norwegian coast, continuing north of the Asian continent to Alaska. July contributed more to this pattern than August. A series of low-pressure systems followed this path, and Oden's track into the pack ice roughly followed the northern edge of this 
anomaly. More quiescent periods of high-pressure weather were also experienced, mostly towards the end of the experiment towards the end of August. Five-day back trajectories to Oden's position showed long periods with rather similar pathways, separated by very abrupt changes corresponding to frontal passages. With the exception of short periods with air from the Greenland Sea or from the Kara Sea area, most trajectories spent at least five days over the pack ice before reaching Oden. The predominant air mass history was similar to the 1996 conditions. Highest wind speeds were associated with the passage of the major frontal systems. However, nearsurface winds were never very strong, always below $12 \mathrm{~m} \mathrm{~s}^{-1}$ and most commonly $3-5 \mathrm{~m} \mathrm{~s}^{-1}$.

The cloud fraction remained close to $100 \%$ for about $70 \%$ of the time or more. Clear conditions prevailed only on a few days during the two months of the expedition. Often ( $49 \%$ of time, cf. Table 4) patchy fog occurred. Near-surface temperature remained in the range between -2 and $-0.5^{\circ} \mathrm{C}$ for around $80 \%$ of the time with two most frequent values, one around zero (ice melting) and around $-1.5^{\circ} \mathrm{C}$ (close to the freezing point for salty ocean water). More details can be found in Tjernström et al. (2004) and in Tjernström (2005).

\subsection{Meteorological conditions during ASCOS-08}

Tjernström et al. (2012) conclude that the ASCOS expedition, from August to early September in 2008, was characterized by a high-pressure anomaly over the Canadian Basin and a low-pressure anomaly over northern Norway into the Kara Sea. The high-pressure anomaly that had an almost barotropic vertical structure generated an anomalous anticyclonic large-scale flow over much of the Arctic Ocean. As a result, several low-pressure systems propagated westward, around the North Pole and across the path of ASCOS in the North-Atlantic sector of the Arctic, especially during the first half of the expedition after which a high-pressure situation dominated almost until the end.

Surface air temperatures varied substantially from near $0^{\circ} \mathrm{C}$ to $-12{ }^{\circ} \mathrm{C}$ but were observed mostly in the -2 to $0^{\circ} \mathrm{C}$ interval. The cold temperatures prevailed in brief colder episodes that start appearing towards the end of August, a feature common to all four expeditions, which was absent earlier in summer. Conditions were consistently very moist, with relative humidities rarely under $90 \%$ while nearsurface winds were most often in the $2-6 \mathrm{~m} \mathrm{~s}^{-1}$ range and seldom $>10 \mathrm{~m} \mathrm{~s}^{-1}$. Over the course of the ASCOS campaign a variety of cloud conditions occurred including deep frontal systems with heavy snow, complex multi-layered systems, boundary layer fogs, and persistent low-level stratiform mixed-phase clouds. In all, clouds occurred more than $90 \%$ of the time. Most trajectories spend at least three days over the pack ice before reaching Oden, a number closest to the IAOE-91 expedition.

\subsection{Air travel times and fog occurrences during the four expeditions}

The cumulative travel times in Fig. 2 show stronger differences in the air masses encountered than visible from the basic statistics in Table 4. Travel times less than two days have been encountered $50 \%$ of the time in 1991, less than $10 \%$ in 1996, and around $30 \%$ of the time in 2001 and 2008. Strong differences also are visible in travel times of four days and longer. Whereas these cases covered only some $10 \%$ in 1991 the corresponding values are $70 \%, 55 \%$, and some $40 \%$ in 1996, 2001, and 2008, respectively.

Low clouds and fogs prevail in the summer Arctic (Eastman and Warren, 2010) and have profound effects on the surface aerosol. Beyond wet scavenging of particles Arctic fogs are suspected to be particle sources (Heintzenberg et al., 2006). Thus occurrence, type and evolution of fogs and their variations will contribute to interannual variations in the measured aerosol data. Unfortunately, the level of fog information varied considerably in between expeditions. In 1991 only hourly and half-hourly meteorological observations were available. In later expeditions forward scattering drop spectrometers (FSSP100, PMS Inc., Boulder CO) were utilized, albeit in different mounting conditions, software operations, and states of calibration. In order to derive a minimum of comparable fog information a parameter quantifying fog occurrence between zero and $100 \%$ during a given hour was calculated from the available information. In 1996 and 2001 fog occurrence was given the value zero for drop number concentrations below $0.1 \mathrm{~cm}^{-3}$ and the value of one for drop concentrations above that threshold. For the 2008 expedition Mathew Shupe (personal communication) calculated a fog occurrence parameter utilizing the FSSP, visibility, and remote sensing data.

Table 4 quantifies the overall interannual variability of fog occurrence in terms of median fog occurrences whereas Figure 3 displays $25 \%, 50 \%$, and $75 \%$ percentiles of fog occurrences for statistics encompassing all four years. Figure 4 confirms these results but shows also that fog occurrence peaked at the first day of travel time from the ice edge followed by a decrease with travel time from the ice edge. Advection of relatively warm moist air transported in over the pack ice is a common cause of fogs during summer and is therefore thought to be dominating in the marginal ice zone. When relatively warm, moist air is transported over the ice it is saturated by cooling from the surface. This process should be slowed down as the air- and surface temperature converges, therefore the probability for advection fogs should be largest in closer to the ice edge. Nilsson and Bigg (1996) found that the probability for a group classified as summer fogs was highest within the first day over the ice and with a weaker probability lasting for two more days. However, as the cooled air continues over the ice it will be close to saturation. Other processes, set by the meteorological conditions, should explain the second peak seen between three to 


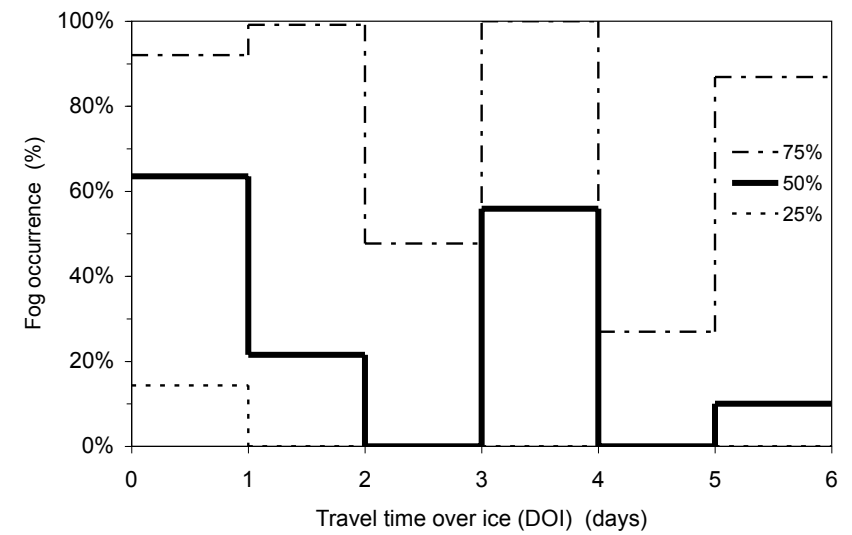

Fig. 3. $25 \%, 50 \%$, and $75 \%$ Percentiles of fog occurrences as a function of travel time over ice (DOI, days). Data for all travel times of five days and longer have been collected in the column 5-6 days.

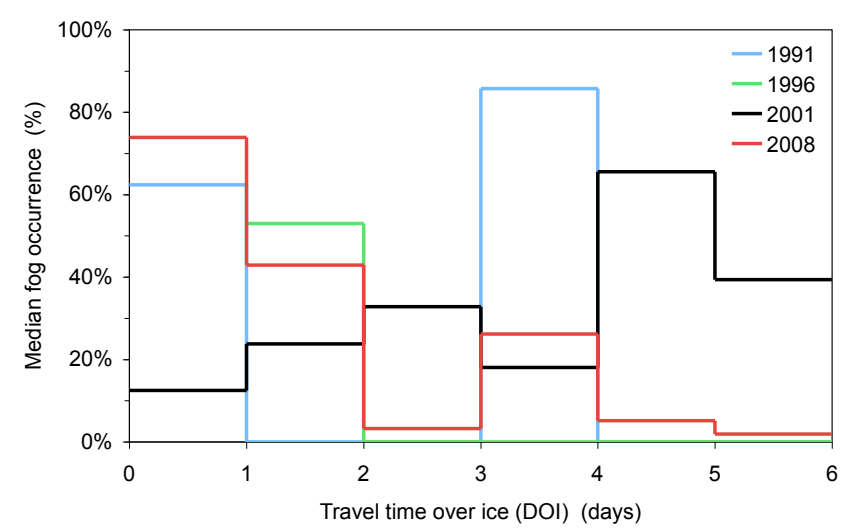

Fig. 4. Median values of fog occurrence per hour in $\%$ as a function of travel time over ice (DOI, days) for the four Oden expeditions.

four days. Mesoscale fronts can trigger its formation; moreover radiation fogs may form as another type of fog during the high pressure situations coinciding with long travel times over the ice in calm conditions with clear sky.

However, the DOI-dependence of fog occurrence varied considerably in between expeditions. In 1991 two clear maxima of fog occurrence were found, one close to the ice edge the other one three to four days into the ice. The few fogs in 1996 occurred mainly one to two days downwind of the ice edge. In 2001 significant fog occurrences were met everywhere from the ice edge with a maximum deep in the central Arctic whereas 2008 appeared similar to 1991.

\section{Structural analysis of the size distributions of the four years}

The structural analysis presented in this section concerns the shape of the sub-micrometer particle size distributions and its potential connection to aerosol forming and transforming processes. For a first structural synopsis of the four years three sub-populations were formed in each data set as a function of the probability distribution function (PDF) of total concentration $N$ taken over all years: All data with $N$ below its $25 \%$ percentile, all data between the $25 \%$ and $75 \%$ percentile of $\mathrm{N}$, and all data above the $75 \%$ percentile of $\mathrm{N}$. Median number size distributions were calculated for each of these three sub-populations and plotted in Fig. 5.

Several features can be gleaned from Fig. 5. Median number size distributions in all three sub-populations in all four years are quite similar in concentration levels and structure. This structure becomes more modal with decreasing total number with mode size positions rather similar over the four years, which will be explored below.

The probability distribution function of geometric mean diameters of the modes of the fitted size distributions displayed in Fig. 5 yields more insights into structural similarities and differences of the four years of aerosol data. Details in the modal structure vary from year to year in Fig. 6a, in particular the sharpness of the peaks in the PDF and the probabilities in the ultrafine size range. The main features of a predominant Aitken peak around $30 \mathrm{~nm}$, a deep minimum of mode occurrence between 50 and $90 \mathrm{~nm}$, and a main accumulation mode occurrence between 100 and $150 \mathrm{~nm}$, however, are very similar in all years.

After weighting the frequencies of occurrence of modes with their respective contributions to the total number as shown in Fig. $6 \mathrm{~b}$ the most important modes become more clearly visible and the results of the four years look more similar, in particular the minimum between Aitken and accumulation mode. To varying extent and distributed between the bottom end of the measured size range and about $20 \mathrm{~nm}$ ultrafine particles contributed to the total $N$ in all four years. The depth of the minimum between Aitken and accumulation mode was deepest in 1991, quite similar in 1996 and 2008, and expressed the least in 2001, meaning that particle modes occurred more frequently in what we shall call "Hoppel gap" in the following after the findings of Hoppel (1986).

For two process-related structural analyses the fitted hourly size distributions of all years were pooled. First, the size distributions were collected in the six sub-populations given in Fig. 7 covering the range of ultrafine particles $\mathrm{N} 26$ of three to $>300 \mathrm{~cm}^{-3}$. Median size distributions in these six sub-populations are drawn in Fig. 7. Interestingly, without ultrafine particles only one mode with a median diameter around $110 \mathrm{~nm}$ and a total number concentration of about ten per cubic centimeter remains. This distribution can be seen as the ultimate leftover after sink processes removed both the smaller particles by diffusion and the larger particles by sedimentation and wet scavenging. Monomodal sub-micrometer number size distributions have been reported from several studies in the clean Antarctic atmosphere. Jaenicke et al. (1992) found such distributions with modal diameters around $40 \mathrm{~nm}$ in the Austral winter at the German Antarctic "Georg von Neumayer" station. 


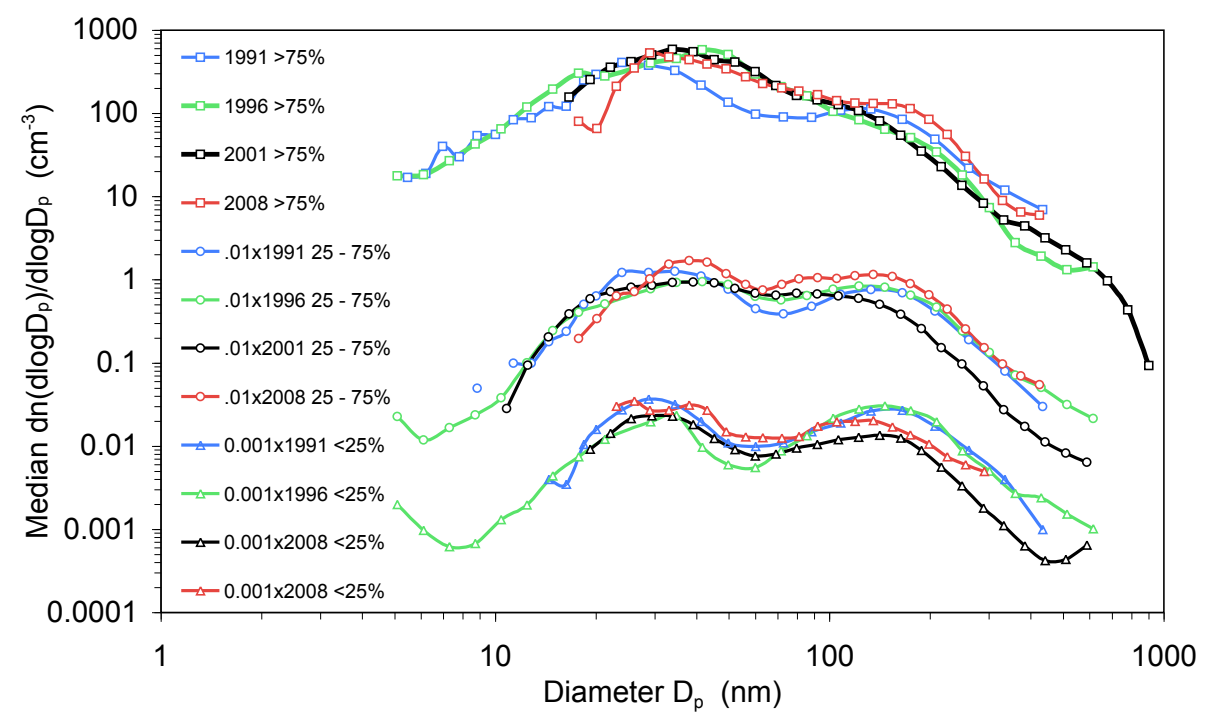

Fig. 5. Median number size distributions in three sub-population of hourly averages of the 1991, 1996, 2001, and 2008 in-ice data: Less than the $25 \%$ percentile, between 25 and $75 \%$ percentile and larger than the $75 \%$ percentile of total number concentration $N$ taken over all four years. The data for the sub-populations $25-75 \%$, and $<25 \%$ have been multiplied by factors of 0.1 , and 0.01 , respectively, in order to avoid overlap in the graph.
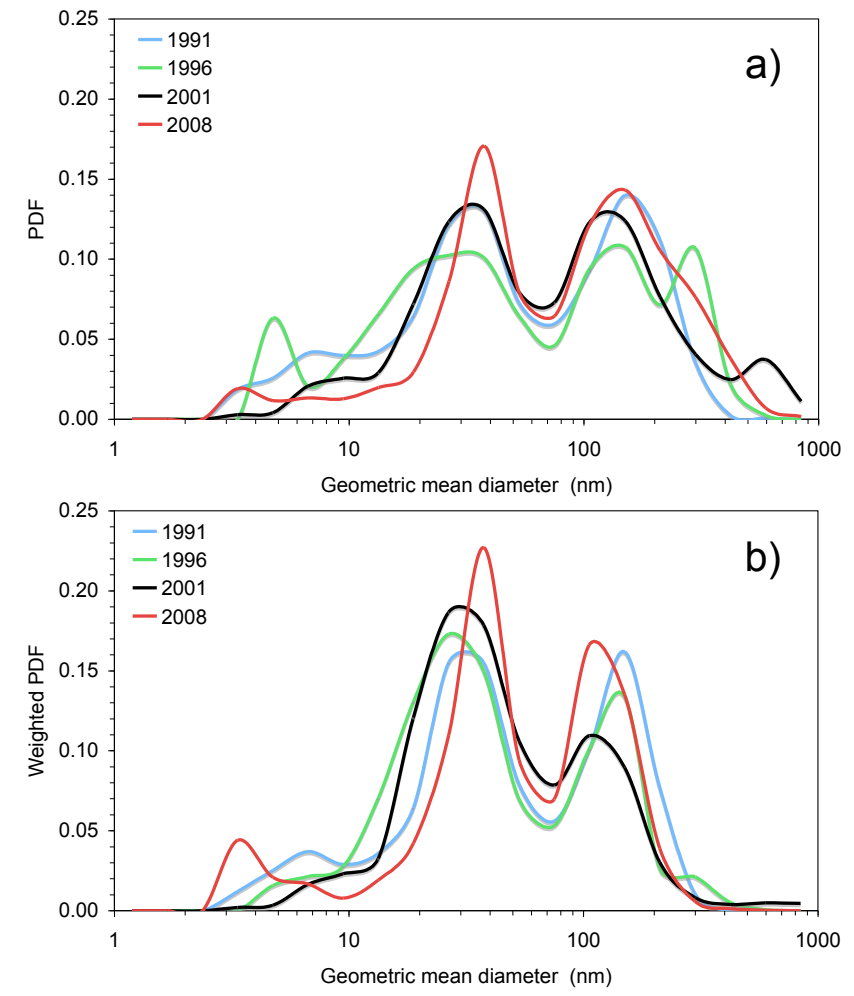

Fig. 6. (a) Probability density function PDF of geometric mean diameters of hourly number size distributions measured in 1991, 1996, 2001, and 2008 fitted with 2-6 lognormal modes; (b) PDFs weighted with the contributions of the respective modes to the actual total number concentration.

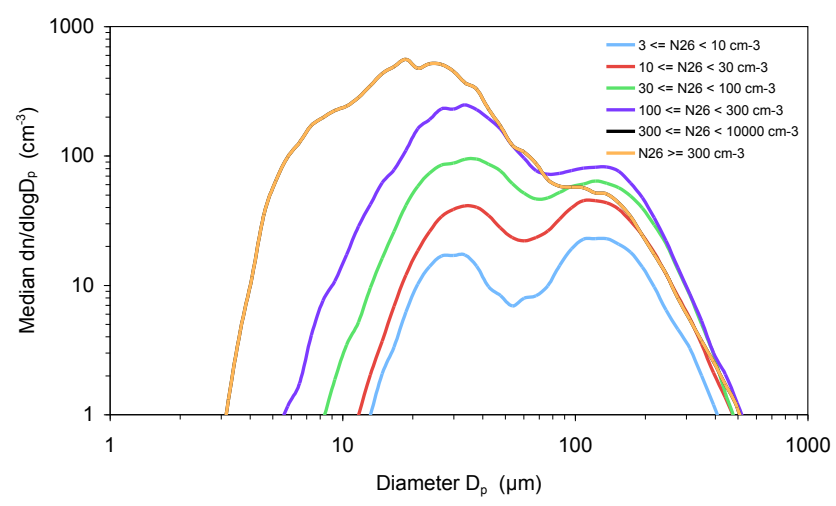

Fig. 7. Median number size distributions fitted with lognormal functions in six sub-populations, in which the concentrations of ultrafine particles was varied between 0 and $>300 \mathrm{~cm}^{-3}$.

When N26 builds up ever more number small particles are added to the size distribution. A mode between 20 and $30 \mathrm{~nm}$ shows up at $\mathrm{N} 26 \geq 3 \mathrm{~cm}^{-3}$, and is maintained and augmented until one broad maximum below about $50 \mathrm{~nm}$ is dominant at the highest N26 concentrations. With increasing N26 the minimum between Aitken and accumulation modes moves from $60 \mathrm{~nm}$ to $90 \mathrm{~nm}$ diameter. This modal build-up of ultrafine particles as measured in the Arctic is not a universal feature of the atmospheric aerosol. In hourly data from 2003 to 2010 at the continental reference station Melpitz (Heintzenberg et al., 1998), e.g., a monomodal distribution at the lowest values of $\mathrm{N} 26\left(<30 \mathrm{~cm}^{-3}\right)$ with a peak at about $110 \mathrm{~nm}$ builds up to a broad and much less structured ultrafine region with modes at $42 \mathrm{~nm}$ and $17 \mathrm{~nm}$ with increasing N26. This 


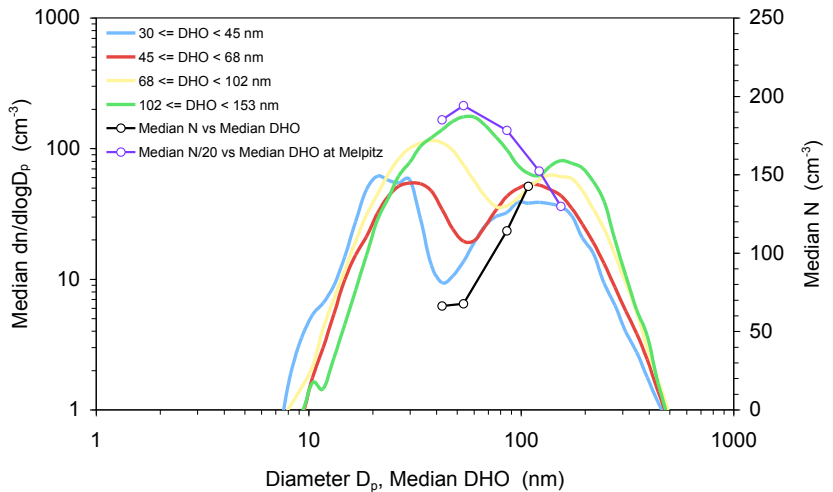

Fig. 8. Median number size distributions fitted with lognormal functions in four sub-populations, with Hoppel diameters (DHO, nm) varying between $30 \mathrm{~nm}$ and $150 \mathrm{~nm}$. Median total number concentrations $\left(\mathrm{N}, \mathrm{cm}^{-3}\right)$ in each sub-population are also plotted as function of median DHO in each sub-population. For comparison total number concentrations scaled by a factor of 20 are plotted as a function of median DHO for the continental reference station Melpitz, Germany.

is consistent with observations of the concurrent appearance of several distinct particle sizes below $50 \mathrm{~nm}$ during typical nucleation events over the pack ice (Leck and Bigg, 1999, 2010; Karl et al., 2012).

In all years the PDF of number modes in Fig. $6 a$, b often showed varying minima of occurrence in the diameter range 50 to $100 \mathrm{~nm}$. This structural feature of the particle size distribution was explored by calculating median number size distributions in sub-populations with varying values of DHO. Varying DHO from 30 to $150 \mathrm{~nm}$ yields the four median size distributions plotted in Fig. 8. Taken over all four years there is a monotonous decrease of median total number $(\mathrm{N})$, with decreasing median Hoppel diameter. This connection between DHO and total number $N$ could be simply due to an increasing total number being mainly caused by an increasing Aitken peak that fills out any nominal Hopple minimum below the accumulation mode or, more likely, could be a product of feedback of increasing $N$ on supersaturation for clouds with low cooling rates. This effect can be tested by sorting the size distributions as a function of $N$ while viewing DHO. With $N$ as the independent variable no clear connection with DHO shows up in the medians of the subpopulations displayed in Fig. 5. Only in 1991 a monotonous increase in DHO is visible with $N$ whereas the data of the other three years only show an apparent increase in DHO for the step from $N<$ its $25 \%$ percentile to $25 \% \leq N<75 \%$ in Fig. 5 and no minimum between Aitken and accumulation mode at all for the data with $N<$ its $75 \%$ percentile.

As another test of the universal (or trivial) character of the connection of DHO and total number, hourly size distributions measured from 2003 to 2010 at the continental reference station Melpitz, Germany have been evaluated in the same way as the high Arctic data. The corresponding results

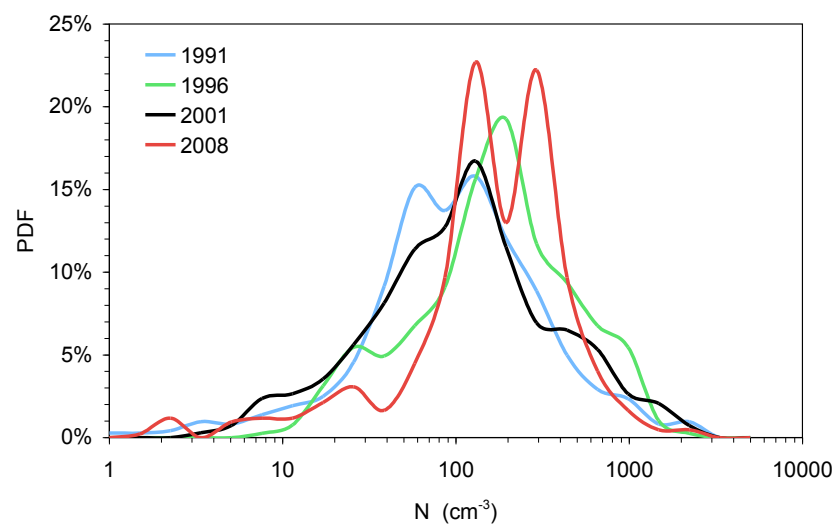

Fig. 9. Probability distribution function PDF of total number concentrations $\left(\mathrm{N}, \mathrm{cm}^{3}\right)$ in 1991, 1996, 2001, and 2008.

are added to Fig. 8 in which the total number concentration at Melpitz (scaled by a factor of 20) decreases with increasing DHO.

In the boundary layer of the pristine remote central summer Arctic cloud formation may be limited by the small available number of $\mathrm{CCN}$ - becoming extremely tenuous (Lannefors et al., 1983; Bigg et al., 1996; Bigg and Leck, 2001a; Leck et al., 2002; Mauritsen et al., 2011). We hypothesize that this limitation leads to higher water vapor supersaturations, which cause ever smaller particles to be cloudactivated with decreasing total particle number. The conditions for cloud formation must be very different near the continental reference station Melpitz with twenty times higher number concentrations yielding the opposite connection between DHO and total number.

\section{Statistic of integral aerosol parameters of the four years}

Statistics of integral parameters of the particle size distributions of the four years are collected in Tables 2, and 3 . No systematic changes from year to year can be seen in any of the median statistical parameters. Taken over all four years median number, surface, and volume concentrations are $109 \mathrm{~cm}^{-3}, 3.0 \mu \mathrm{m}^{2} \mathrm{~cm}^{-3}$, and $0.10 \mu \mathrm{m}^{3} \mathrm{~cm}^{-3}$, respectively. Table 3 gives the statistics for the sub-populations ultrafine (N26), Aitken particles (NAIT), and accumulation mode (NACC) as defined in section 3. Again, there are no systematic changes in the observed median levels.

For the total number $N$ a more detailed statistical comparison of the four years is displayed in terms of probability distribution functions (PDF) in Fig. 9. With the exception of the relatively high number concentrations encountered in 1996 the PDFs are centered around $100 \mathrm{~cm}^{-3}$.

Statistics of the Hoppel diameters for the different years can be found in Table 4 . Their percentiles between 42 and $310 \mathrm{~nm}$ are mostly significantly smaller than the range of 100 
Table 3. As Table 2 but for ultrafine particles $\left(\mathrm{N} 26, \mathrm{~cm}^{-3}\right)$, for particles larger than $26 \mathrm{~nm}$ and smaller than the calculated Hoppel-diameter DHO (NAIT, $\mathrm{cm}^{-3}$ ), and particles larger than DHO and smaller than $600 \mathrm{~nm}\left(\mathrm{NACC}, \mathrm{cm}^{-3}\right)$. Additionally, the fraction of time with $\mathrm{N} 26$ $>100 \mathrm{~cm}^{-3}$ is given.

\begin{tabular}{lcccccccccc}
\hline Year & N26 & N26 & N26 & NAIT & NAIT & NAIT & NACC & NACC & NACC & $\%$ of hours \\
\hline Quantile & $5 \%$ & $50 \%$ & $95 \%$ & $5 \%$ & $50 \%$ & $95 \%$ & $5 \%$ & $50 \%$ & $95 \%$ & N26 $>100 \mathrm{~cm}^{-3}$ \\
1991 & 4 & 44 & 400 & 1.7 & 25 & 180 & 1.2 & 28 & 120 & 9 \\
1996 & 6 & 85 & 640 & 3.0 & 46 & 210 & 4.0 & 29 & 100 & 14 \\
2001 & 2 & 36 & 500 & 2.5 & 25 & 250 & 0.4 & 12 & 60 & 3 \\
2008 & 1 & 59 & 440 & 2.0 & 45 & 210 & 1.6 & 50 & 100 & 12 \\
\hline
\end{tabular}

Table 4. As Table 2 but for the travel time of back trajectories over ice (DOI, days), and for median values of the Hoppel-diameter (DHO, nm). Additionally, the percentage of fog occurrences and of hourly size distribution records with Hoppel-diameter are given.

\begin{tabular}{lcccccccc}
\hline Year & DOI & DOI & DOI & DHO & DHO & DHO & $\%$ of hours & $\%$ of hours \\
\hline Quantile & $5 \%$ & $50 \%$ & $95 \%$ & $5 \%$ & $50 \%$ & $95 \%$ & with fog & with DHO \\
1991 & 0.6 & 2.1 & 4.8 & 48 & 68 & 137 & 37 & 90 \\
1996 & 1.9 & 5.0 & 5.0 & 42 & 68 & 122 & 23 & 88 \\
2001 & 1.0 & 5.0 & 5.0 & 48 & 68 & 310 & 46 & 72 \\
2008 & 0.9 & 3.3 & 5.0 & 48 & 68 & 137 & 36 & 85 \\
\hline
\end{tabular}

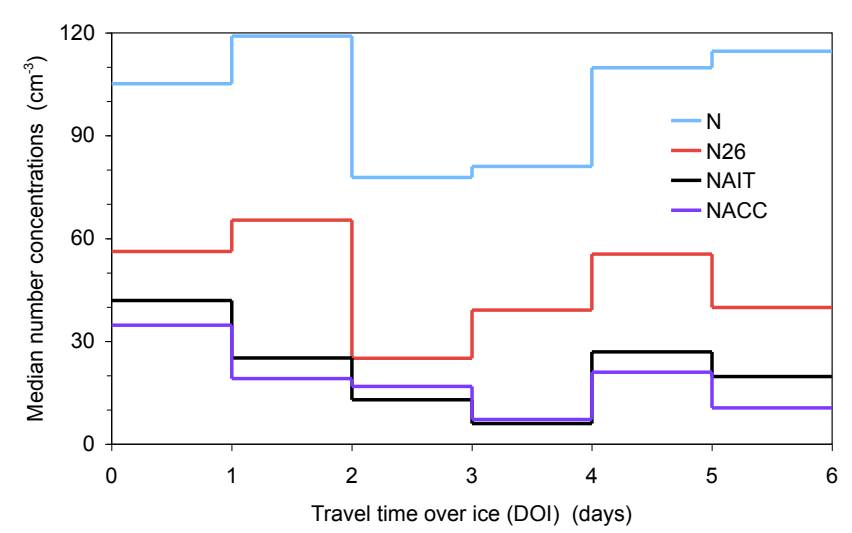

Fig. 10. Median total number $\left(\mathrm{N}, \mathrm{cm}^{-3}\right)$, number concentration below $26 \mathrm{~nm}$ particle diameter $\left(\mathrm{N} 26, \mathrm{~cm}^{-3}\right)$, number concentration (NAIT, $\mathrm{cm}^{-3}$ ) between $26 \mathrm{~nm}$ and Hoppel diameter DHO, and number concentration between DHO and $600 \mathrm{~nm}\left(\mathrm{NACC}, \mathrm{cm}^{-3}\right)$ as a function of travel time over ice (DOI, days). Data for all travel times of five days and longer have been collected in the column 5-6 days.

to $160 \mathrm{~nm}$ given for marine aerosols in Hoppel (1986). They are, however, only slightly lower than the minima in the number size distributions of the marine aerosol review in Fig. 7 of Heintzenberg et al. (2004). The similarity of numerical DHO values in Table 4 could have been suspected already from the PDF of geometric mean diameters in Fig. 6b. In part it is also due to the method of searching DHO in a fixed array of 60 diameters of the fitted lognormal size distributions covering a range of one to $1000 \mathrm{~nm}$ in $12 \%$ steps. The diameter step in this fixed array consequently represents the inherent un- certainty in the DHO search. No significant change of DHO with travel time over ice was found.

\section{Aerosol transport over the pack ice}

Understanding possible inter-annual variability in the integral parameters of the particle size distributions will also require an understanding of the synoptic scale systems advecting heat, moisture, and particles from the surrounding open seas south of the ice edge for a variable length of time over the pack ice. Advection of aerosol particles from the ice edge, in-situ new particle formation, and physical and chemical transformations over the pack ice will affect the shape of the observed particle size distributions at the location of the ship. We will utilize the travel time over ice (DOI) as a simple parameter to summarize the evolution of the aerosol since its last contact with open water.

In Heintzenberg et al. (2006) the connection between integral aerosol parameters and the travel time from the ice edge to the measurement point was discussed for the expedition years 1991 to 2001. Here we extend and generalize this discussion by combining the results of all four years in Fig. 10. In this figure travel times of five days and longer have been collected in the column 5-6 days.

Close to the ice edge after travel times up to two days Fig. 10 indicates a sink region of Aitken (NAIT), and accumulation mode (NACC) particles. Concentration minima of both modes for $3 \leq \mathrm{DOI}<4$ days coincide with the secondary maximum in fog occurrence in Fig. 3 beyond which all integral median number concentrations increase again with travel time further into the pack ice, being most 
Table 5. Statistics of mode parameters of the summer aerosol in the central Arctic in the three diameter ranges UFP: 1-26 nm, AIT: 26$80 \mathrm{~nm}$, and ACC: $80-1000 \mathrm{~nm}$. $\mathrm{Nm}=$ total number per mode in $\mathrm{cm}^{-3}, \mathrm{Dg}=$ geometric mean diameter in nm, and Sig = geometric standard deviation.

\begin{tabular}{lccccccccc}
\hline Mode & $\mathrm{Nm}$ & $\mathrm{Nm}$ & $\mathrm{Nm}$ & $\mathrm{Dg}$ & $\mathrm{Dg}$ & $\mathrm{Dg}$ & $\mathrm{Sig}$ & $\mathrm{Sig}$ & Sig \\
\hline Percentile & $5 \%$ & $50 \%$ & $95 \%$ & $5 \%$ & $50 \%$ & $95 \%$ & $5 \%$ & $50 \%$ & $95 \%$ \\
UFP $(1-26 \mathrm{~nm})$ & 1.1 & 44 & 912 & 4 & 15 & 25 & 1.1 & 1.3 & 2.1 \\
AIT $(26-80 \mathrm{~nm})$ & 4.6 & 81 & 633 & 27 & 40 & 72 & 1.2 & 1.4 & 2.0 \\
ACC $(80-1000 \mathrm{~nm})$ & 1.5 & 28 & 175 & 90 & 153 & 351 & 1.2 & 1.4 & 2.0 \\
\hline
\end{tabular}

pronounced in the number concentration below $26 \mathrm{~nm}$ particle diameter $\left(\mathrm{N} 26, \mathrm{~cm}^{-3}\right)$,

In marine air aged up to three days over the ice covered central Arctic Ocean Nilsson and Leck (2002) found wet deposition by drizzle and fog drops to be the dominant sink of the accumulation mode particles measured during IAOE91. Here we use the same argument for subsequent expeditions (cf. Fig. 4 and Table 4). This scavenging process corresponded to a turnover time of 15:00-22:00 UTC. Beyond three days of transport, as a result of less drizzle and less dense fogs that lift followed by the formation of stratus it was suggested that less efficient deposition processes remain, which would correspond to turnover times of several days for accumulation mode aerosol particles. This selective "filter" effect has been discussed by Heintzenberg et al. (2006) for the expedition years 1991 through 2001: Based on statistics of modal concentrations a strong concentration decrease of large accumulation mode particles with increasing length of time spent over the pack ice was found in that study. After the initial "filter effect" the travel-time dependencies from 1991 through 2008 are indicative of particle sources in the subsections NACC, NAIT, and N26 in the inner Arctic, as the results of other independent analyses suggested before (Leck and Bigg, 1999, 2005b, 2010; Bigg and Leck, 2001b; Kerminen and Leck, 2001; Leck et al., 2002).

During ASCOS-08 Held et al. (2011a, b) carried out direct eddy covariance measurements of particle number fluxes and found episodic particle emissions from open leads. Simultaneous and independent gradient measurements of particle concentrations presented in Held et al. (2011b) corroborate the finding that open leads can indeed act as particle sources in the Arctic Ocean. Overall, the direct contribution of the open lead particle emissions to the atmospheric aerosol number concentration could only explain a few percent of the observed total particle number variability measured onboard the ship. Unfortunately, no information about the size of the emitted particles was available from these direct flux measurements so a direct comparison with different particle modes cannot be done. Note also that the measured flux data represent a point measurement whereas the sampling at the ship is an integrated measurement from all contributing sources accumulated during travel time over the pack ice.
What past studies have shown is that there is a potential for the polymer gels with their partially granular structures (Leck and Bigg, 2005a, 2010; Orellana et al., 2011) to separate into fragments having sizes within the N26 mode. In several analyzed events, observed in 1996, 2001, and 2008, conventional state-of-the-art nucleation mechanisms (Karl et al., 2012) applied in numerical models could not explain the simultaneous number enhancement of particles in the $20-50 \mathrm{~nm}$ diameter size range. The analyzed cases covered the central Arctic, the marginal ice zone and open waters. This suggests the consideration of alternative particle formation hypotheses such as the fragmentation of marine polymer gels (about 200-500 nm diameter in size). From a progressive stepwise fragmentation of large particles a tendency for concentrations of larger particles to be enhanced before small ones in Arctic new particle formation events would be expected and can possibly be inferred from the evolution of particle size distributions with increasing N26 in Fig. 7. A simultaneous concentration increase at several sub-micrometer particle sizes could also be due to the mixing of air from different levels or source regions having different particle size distributions but would require more complex assumptions. Leck and Bigg $(1999,2010)$ suggested that the disruption of particles by electric charges might provide an appropriate fragmentation mechanism. This type of process appears consistent with observation since it would be favored by evaporation of cloud or haze drops; however it needs further elaboration. The presence of such a fragmentation mechanism could also serve as a model to explain why only a few percent of the observed total particle number variability measured onboard the ship was explained by the direct eddy covariance measurements of particle number fluxes at the open lead site. In summary the combined results of four expeditions confirm earlier findings that the most remote ice-covered inner Arctic, defined by maximum travel times is not a pure sink area but exhibits aerosol sources that raise total number and also number concentrations in the given sub-ranges of particle size.

\section{Conclusions}

In the course of global warming dramatic changes are taking place in the Arctic and boreal environments. More than $2200 \mathrm{~h}$ of physical aerosol data in from the central summer 
Arctic taken over the course of 17 years from 1991 to 2008 show no systematic changes, albeit substantial interannual variations, in spite of significant changes in ice extent and thickness. The lack of an aerosol response suggests that the processes controlling concentrations and particle size distribution of the aerosol over the central Arctic may not have changed substantially during this time. Environmental changes in marine biological activity are still mainly effective in the marginal ice zone, the ice-free waters and continental rims and have not propagated significantly into the central Arctic yet where they could affect the local aerosol and its sources. The analysis of meteorological conditions of the four expedition summers reveal substantial variations which we see as main causes of the measured variations in aerosol parameters and the lack of systematic year-to-year changes.

With the combined lognormal fits of the hourly number size distributions of the four expeditions representative mode parameters for the summer aerosol in the central Arctic have been calculated. In Table 5 statistics of these parameters are collected in the three diameter ranges $1-26 \mathrm{~nm}, 26-80 \mathrm{~nm}$, and $80-1000 \mathrm{~nm}$.

The combined aerosol statistics summarized in Table 5 and discussed in the present paper provide comprehensive physical data on the summer aerosol in the central Arctic with some connections to its formation and transformation processes. These data are the only surface aerosol information from this region.

Acknowledgements. This work is part of ASCOS (the Arctic Summer Cloud-Ocean Study). ASCOS was an IPY project under the AICIA-IPY umbrella and an endorsed SOLAS project. ASCOS was made possible by funding from the Knut and Alice Wallenberg Foundation, the DAMOCLES Integrated Research Project from the European Union 6th Framework Program and by the Bert Bolin Center for Climate Research. We thank Douglas Orsini who took the size distribution measurements during the 2008 expedition, calibrated the instruments, and inverted the results. Mathew Shupe kindly evaluated the fog information for ASCOS-08. We are also very grateful to Michael Tjernström for his co-organizing ASCOS. The Swedish Polar Research Secretariat (SPRS) provided access to the icebreaker Oden and logistical support. Mathias Karl provided valuable comments to the discussion of nucleation. Finally we are greatly indebted to the Oden's Captain Mattias Peterson and his crew for invaluable assistance with a multitude of logistic matters.

Edited by: I. Brooks

\section{References}

Bigg, E. K. and Leck, C.: Cloud-active particles over the central Arctic Ocean, J. Geophys. Res., 106, 32155-32166, 2001a.

Bigg, E. K. and Leck, C.: Properties of the aerosol over the central Arctic Ocean, J. Geophys. Res., 106, 32101-32,109, 2001 b.
Bigg, E. K. and Leck, C.: The composition of fragments of bubbles bursting at the ocean surface, J. Geophys. Res., 113, D11209, doi:10.1029/12007JD009078, 2008.

Bigg, E. K., Leck, C., and Nilsson, E. D.: Sudden changes in Arctic atmospheric aerosol concentrations during summer and autumn. Tellus 48B, 254-271, 1996.

Birmili, W., Stratmann, F., Wiedensohler, A., Covert, D., Russell, L. M., and Berg, O.: Determination of differential mobility analyzer transfer functions using identical instruments in series, Aerosol Sci. Technol., 27, 215-223, 1997.

Blanchard, D. C. and Woodcock, A. H.: Bubble formation and modification in the sea and its meteorological significance, Tellus, 9, 145-158, 1957.

Covert, D. S., Wiedensohler, A., Aalto, P., Heintzenberg, J., McMurry, P. H., and Leck, C.: Aerosol number size distributions from 3 to $500 \mathrm{~nm}$ diameter in the arctic marine boundary layer during summer and autumn. Tellus 48B, 197-212, 1996.

Doherty, S. J., Warren, S. G., Grenfell, T. C., Clarke, A. D., and Brandt, R. E.: Light-absorbing impurities in Arctic snow, Atmos. Chem. Phys., 10, 11647-11680, doi:10.5194/acp-1011647-2010, 2010.

Draxler, R. and Rolph, G.: HYSPLIT (HYbrid Single-Particle Lagrangian Integrated Trajectory) Model access via NOAA ARL READY. NOAA Air Resources Laboratory, Silver Spring, MD, USA, 2003.

Eastman, R. and Warren, S. G.: Interannual variations of Arctic cloud types in relation to sea ice, J. Clim., 23, 4216-4232, 2010.

Gao, Q., Leck, C., Rauschenberg, C., and Matrai, P. A.: On the chemical dynamics of extracellular polysaccharides in the high Arctic surface microlayer, Ocean Sci. Discuss., 9, 215-259, doi:10.5194/osd-9-215-2012, 2012.

Hansen, J. and Nazarenko, L.: Soot climate forcing via snow and ice albedos, PNAS, 101, 423-428, 2003.

Heintzenberg, J., Birmili, W., Wiedensohler, A., Nowak, A., and Tuch, T.: Structure, variability and persistence of the submicrometer marine aerosol, Tellus, 56B, 357-367, 2004.

Heintzenberg, J., Leck, C., Birmili, W., Wehner, B., Tjernström, M., and Wiedensohler, A.: Aerosol number-size distributions during clear and fog periods in the summer high Arctic: 1991, 1996, and 2001, Tellus, 58B, 41-50, 2006.

Heintzenberg, J., Müller, K., Birmili, W., Spindler, G., and Wiedensohler, A.: Mass-related aerosol properties over the Leipzig Basin, J. Geophys. Res., 103, 13125-13135, 1998.

Held, A., Brooks, I. M., Leck, C., and Tjernström, M.: On the potential contribution of open lead particle emissions to the central Arctic aerosol concentration, Atmos. Chem. Phys., 11, 30933105, doi:10.5194/acp-11-3093-2011, 2011a.

Held, A., Orsini, D. A., Vaattovaara, P., Tjernström, M. and Leck, C.: Near-surface profiles of aerosol number concentration and temperature over the Arctic Ocean, Atmos. Meas. Tech., 4, 1603-1616, doi:10.5194/amt-4-1603-2011, 2011 b.

Hoppel, W. A., Frick, G. M., and Larson, R. E.: Effect of nonprecipitating clouds on the aerosol size distribution in the marine boundary layer, Geophys. Res. Lett., 13, 125-128, 1986.

Intrieri, J. M., Fairall, C. W., Shupe, M. D., Persson, P. O. G., Andreas, E. L., Guest, P. S., and Moritz, R. E.: An annual cycle of Arctic surface cloud forcing at SHEBA, J. Geophys. Res., 107, 8039, doi:8010.1029/2000JC000439, 2002. 
Jaenicke, R., Dreiling, V., Lehmann, E., Koutsenoguii, P. K., and Stingl, J.: Condensation nuclei at the German Antarctic Station "Georg von Neumayer", Tellus, 44B, 311-317, 1992.

Karl, M., Leck, C., Gross, A., and Pirjola, L.: A Study of New Particle Formation in the Marine Boundary Layer Over the Central Arctic Ocean using a Flexible Multicomponent Aerosol Dynamic Model, Tellus, 64B, 17158, doi:10.13402/tellusb.v17164i17150.17158, 2012.

Kattsov, V. M., Ryabinin, V. E., Overland, J. E., Serreze, M. C., Visbeck, M., Walsh, J. E., Meier, W., and Zhang, X. D.: Arctic sea-ice change: a grand challenge of climate science, J. Glaciol., 57, 1115-1121, 2010.

Kay, J. E., Holland, M. M., and Jahn, A.: Inter-annual to multidecadal Arctic sea ice extent trends in a warming world, Geophys. Res. Lett., 38, L15708, doi:10.1029/2011g1048008, 2011.

Kerminen, V.-M. and Leck, C.: Sulfur chemistry over the Central Arctic Ocean in summer: Gas to particulate transformation, J. Geophys. Res., 106, 32087-32100, 2001.

Koch, D., Bauer, S. E., Del Genio, A., Faluvegi, G., McConnell, J. R., Menon, S., Miller, R. L., Rind, D., Ruedy, R., Schmidt, G. A., and Shindell, D.: Coupled Aerosol-Chemistry-Climate Twentieth-Century Transient Model Investigation: Trends in Short-Lived Species and Climate Responses, J. Clim., 24, 26932714, 2011.

Kwok, R., Cunningham, G. F., Wensnahan, M., Rigor, I., Zwally, H. J., and Yi, D.: Thinning and volume loss of the Arctic Ocean sea ice cover: 2003-2008, J. Geophys. Res., 114, C07005, doi:10.1029/2009jc005312, 2009.

Kwok, R. and Rothrock, D. A.: Decline in Arctic sea ice thickness from submarine and ICESat records: 1958-2008, Geophys. Res. Lett., 36, L15501, 2009.

Lannefors, H., Heintzenberg, J., and Hansson, H.-C.: A comprehensive study of physical and chemical parameters of the Arctic summer aerosol; results from the Swedish expedition Ymer-80, Tellus, 35B, 40-54, 1983.

Leck, C. and Bigg, E. K.: Aerosol production over remote marine areas - A new route, Geophys. Res. Lett., 23, 3577-3581, 1999.

Leck, C. and Bigg, E. K.: Biogenic particles in the surface microlayer and overlaying atmosphere in the central Arctic Ocean during summer, Tellus, 57B, 305-316, $2005 \mathrm{a}$.

Leck, C. and Bigg, E. K.: Source and evolution of the marine aerosol - A new perspective, Geophys. Res. Lett., 32, L19803, doi:10.1029/12005GL023651, 2005b.

Leck, C. and Bigg, E. K.: New particle formation of marine biological origin, Aerosol Sci. Technol., 44, 570-577, 2010.

Leck, C., Bigg, E. K., Covert, D. S., Heintzenberg, J., Maenhaut, W., Nilsson, E. D., and Wiedensohler, A.: Overview of the atmospheric research program during the International Arctic Ocean Expedition of 1991 (IAOE-91) and its scientific results, Tellus, 48B, 136-155, 1996.

Leck, C., Nilsson, E. D., Bigg, E. K., and Bäcklin, L.: The atmospheric program on the Arctic Ocean Expedition 1996 (AOE96): An overview of scientific goals, experimental approach, and instruments, J. Geophys. Res., 106, 32051-32067, 2001.

Leck, C., Norman, M., Bigg, E. K., and Hillamo, R.: Chemical composition and sources of the high Arctic aerosol relevant for cloud formation. J. Geophys. Res., 107, 4135, doi:10.1029/2001JD001463, 2002.
Leck, C. and Persson, C.: Seasonal and short-term variability in dimethyl sulfide, sulfur dioxide and biogenic sulfur and sea salt aerosol particles in the arctic marine boundary layer, during summer and autumn, Tellus, 48B, 272-299, 1996 a.

Leck, C. and Persson, C.: The central Arctic Ocean as a source of dimethyl sulfide: Seasonal variability in relation to biological activity, Tellus, 48B, 156-177, 1996b.

Leck, C., Tjernström, M., Matrai, P., Swietlicki, E., and Bigg, K.: Can marine micro-organisms influence melting of the Arctic pack ice?, EOS, 85, 25-36, 2004.

Lewis, E. R. and Schwartz, S. E.: Sea salt aerosol production: Mechanisms, methods, measurements and models - A critical review, Washington DC, USA, American Geophysical Union, 2004.

Liu, Y., Key, J. R., and Wang, X.: Influence of changes in sea ice concentration and cloud cover on recent Arctic surface temperature trends, Geophys. Res. Lett., 36, L20710, doi:10.1029/2009g1040708, 2009.

Lohmann, U. and Leck, C.: Importance of submicron surface active organic aerosols for pristine Arctic clouds, Tellus 57B, 261-268, 2005.

Maslanik, J., Stroeve, J., Fowler, C., and Emery, W.: Distribution and trends in Arctic sea ice age through spring 2011, Geophys. Res. Lett., 38, L13502, doi:10.1029/2011gl047735, 6, 2011.

Mauritsen, T., Sedlar, J., Tjernström, M., Leck, C., Martin, M., Shupe, M., Sjogren, S., Sierau, B., Persson, P. O. G., Brooks, I. M., and Swietlicki, E.: An Arctic CCN-limited cloud-aerosol regime, Atmos. Chem. Phys., 11, 165-173, doi:10.5194/acp-11165-2011, 2011.

McGrath, R.: Trajectory models and their use in the Irish Meteorological Service, Irish Meteorological Service, Dublin, UK, 1989.

Nilsson, E. D.: Planetary boundary layer structure and air mass transport during the International Arctic Ocean Expedition 1991, Tellus 48B, 178-196, 1996.

Nilsson, E. D. and Barr, S.: Effets of synoptic patterns on atmospheric chemistry and aerosols during the Arctic Ocean Expedition 1996, J. Geophys. Res., 106, 32069-32086, 2001.

Nilsson, E. D. and Bigg, E. K.: Influences of formation and dissipation of high Arctic fogs during summer and autumn and their interaction with aerosol, Tellus, 48B, 234-253, 1996.

Nilsson, E. D. and Leck, C.: A pseudo-Lagrangian study of the sulfur budget in the remote Arctic marine boundary layer, Tellus B 54, 213-230, 2002.

Norris, S. J., Brooks, I. M., de Leeuw, G., Sirevaag, A., Leck, C., Brooks, B. J., Birch, C. E., and Tjernström, M.: Measurements of bubble size spectra within leads in the Arctic summer pack ice, Ocean Sci., 7, 129-139, doi:10.5194/os-7-129-2011, 2011.

Ogren, J. A. and Heintzenberg, J.: Parametric aerosol sampling at low concentration levels, Department of Meteorology, Stockholm University, Sweden, 1990.

Orellana, M. V., Matrai, P. A., Leck, C., Rauschenberg, C. D., Lee, A. M., and Coz, E.: Marine microgels as a source of cloud condensation nuclei in the high Arctic, PNAS, 108, 13612-13617, 2011.

Paatero, J., Vaattovaara, P., Vestenius, M., Meinander, O., Makkonen, U., Kivi, R., Hyvärinen, A., Asmi, E., Tjernström, M., and Leck, C.: Finnish contribution to the Arctic Summer Cloud Ocean Study (ASCOS) expedition, Arctic Ocean 2008, Geophysica, 45, 119-146, 2009. 
Rampal, P., Weiss, J., and Marsan, D.: Positive trend in the mean speed and deformation rate of Arctic sea ice, 1979-2007, J. Geophys. Res.-Ocean., 114, C05013, doi:10.1029/2008jc005066, 2009.

Sedlar, J., Tjernström, M., Mauritsen, T., Shupe, M. D., Brooks, I. M., Persson, P. O. G., Birch, C. E., Leck, C., Sirevaag, A., and Nicolaus, M.: A transitioning Arctic surface energy budget: the impacts of solar zenith angle, surface albedo and cloud radiative forcing, Clim. Dynam. 11, 1-18, 2010.

Serreze, M. C. and Barry, R. G.: Processes and impacts of Arctic amplification: A research synthesis, Global Planet. Change 77, 85-96, 2011.

Smith, W. O. and Nelson, D. M.: Phytoplankton Bloom Produced by a Receding Ice Edge in the Ross Sea: Spatial Coherence with the Density Field, Science, 227, 163-166, 1985.

Spurny, K. R.: Atmospheric condensation nuclei P. J. Coulier 1875 and J. Aitken 1880 (Historical review), Aerosol Sci. Technol., 32, 243-248, 2000.

Stolzenburg, M. R.: An ultrafine aerosol size distribution measuring system, Ph. D. Thesis, Department, University of Minnesota, Minneapolis, USA, 1988.

Stratmann, F., Orsini, D., and Kauffeldt, T.: Inversion algorithm for TDMA measurements. J. Aerosol Sci. 28, S701-S702, 1997.

Tjernström, M.: The summer Arctic boundary layer during the Arctic Ocean Experiment 2001 (AOE-2001), Bound.-Layer Meteor. 117, 5-36, 2005.

Tjernström, M., Birch, C., Brooks, I., Leck, C., Mauritsen, T., Paatero, J., Persson, O., Sedlar, J., Shupe, M., Szczodrak, M., and Wheeler, C.: Central Arctic atmospheric conditions during the Arctic Summer Cloud Ocean Study (ASCOS) field phase: Contrasting to previous expeditions, Atmos. Chem. Phys., in preparation, 2012.
Tjernström, M., Leck, C., Persson, P. O. G., Jensen, M. L., Oncley, S. P., and Targino, A.: The Summertime Arctic Atmosphere: Meteorological Measurements during the Arctic Ocean Experiment 2001, Bull. Amer. Meteor. Soc., 85, 1305-1321, 2004.

Tremblay, J., Belanger, S., Barber, D. G., Asplin, M., Martin, J., Darnis, G., Fortier, L., Gratton, Y., Link, H., Archambault, P., Sallon, A., Michel, C., Williams, W. J., Philippe, B., and Gosselin, M.: Climate forcing multiplies biological productivity in the coastal Arctic Ocean, Geophys. Res. Lett., 38, L18604, doi:10.1029/2011g1048825, 2011.

Vavrus, S., Holland, M. M., and Bailey, D. A.: Changes in Arctic clouds during intervals of rapid sea ice loss, Clim. Dynam., 36, 1475-1489, 2011.

Whitby, K. T.: The physical characteristics of sulfur aerosols, Atmos. Environ., 12, 135-159, 1978.

Wiedensohler, A.: An approximation of the bipolar charge distribution for particles in the submicron size range, J. Aerosol Sci. 19, 387-389, 1988.

Zhang, J., Spitz, Y. H., Steele, M., Ashjian, C., Campbell, R., Berline, L., and Matrai, P.: Modeling the impact of declining sea ice on the Arctic marine planktonic ecosystem, J. Geophys. Res., 115, C10015, doi:10.1029/2009jc005387, 2010. 